\title{
Phylogeny, taxonomy and diversification events in the Caliciaceae
}

\author{
Maria Prieto $^{1,2} \cdot$ Mats Wedin $^{1}$
}

Received: 21 December 2015/Accepted: 19 July 2016/Published online: 1 August 2016

(C) The Author(s) 2016. This article is published with open access at Springerlink.com

\begin{abstract}
Although the high degree of non-monophyly and parallel evolution has long been acknowledged within the mazaediate Caliciaceae (Lecanoromycetes, Ascomycota), a natural re-classification of the group has not yet been accomplished. Here we constructed a multigene phylogeny of the Caliciaceae-Physciaceae clade in order to resolve the detailed relationships within the group, to propose a revised classification, and to perform a dating study. The few characters present in the available fossil and the complex character evolution of the group affects the interpretation of morphological traits and thus influences the assignment of the fossil to specific nodes in the phylogeny, when divergence time analyses are carried out. Alternative fossil assignments resulted in very different time estimates and the comparison with the analysis based on a secondary calibration demonstrates that the most likely placement of the fossil is close to a terminal node rather than a basal placement in the Calicium clade. Our dating analysis show two successive events giving rise to main clades of mazaediate taxa within the Caliciaceae, in the Upper-Lower Cretaceous boundary and in the Paleocene. As a result of this study, Cyphelium is synonymized with Calicium, Acolium is resurrected, and the new genera Allocalicium and Pseudothelomma are described. Twelve new combinations are proposed: Acolium karelicum, Acolium marcianum, Allocalicium adaequatum, Calicium carolinianum, Calicium lecideinum, Calicium lucidum, Calicium notarisii,
\end{abstract}

Maria Prieto

maria.prieto@nrm.se

1 Department of Botany, Swedish Museum of Natural History, PO Box 50007, 10405 Stockholm, SE, Sweden

2 Departamento de Biología y Geología, Física y Química Inorgánica, Universidad Rey Juan Carlos, C/ Tulipan s/n; 28933 Mostoles, Madrid, Spain
Calicium pinicola, Calicium trachyliodes, Pseudothelomma occidentale, Pseudothelomma ocellatum and Thelomma brunneum. A key for the mazaedium-producing Caliciaceae is included.

Keywords Allocalicium gen. nov. · Calicium fossil · Divergence time estimates $\cdot$ Lichens $\cdot$ Multigene . Pseudothelomma gen. nov

\section{Introduction}

Caliciaceae is one of several ascomycete groups characterized by producing prototunicate (thin-walled and evanescent) asci and a mazaedium (an accumulation of loose, maturing spores covering the ascoma surface). These are traits connected with passive dispersal of the ascospores. For a long time, Caliciaceae was classified together with all other mazaediate and otherwise similar fungi in the order Caliciales, a presumably monophyletic group among ascomycete fungi, until Tibell (1984) suggested that most of the group was a highly polyphyletic assemblage of taxa, which had developed a mazaedium and passive spore dispersal independently. Subsequent phylogenetic studies supported this view (Gargas and Taylor 1995; Gargas et al. 1995; Wedin and Tibell 1997; Lumbsch et al. 2004, 2009; Hibbett et al. 2007; Tehler et al. 2009; Prieto et al. 2013) showing that mazaediate fungi are clearly dispersed over the phylogenetic tree of Ascomycota.

The family Caliciaceae belongs to the Lecanoromycetes (Wedin and Tibell 1997), the largest class of lichenized Fungi (Kirk et al. 2008). Despite the substantial recent advances in the understanding of Lecanoromycetes evolution at both supraordinal level (e.g. Lumbsch et al. 2004; Wedin et al. 2005; Miadlikowska et al. 2006, 2014) and lower levels (i.e. family and genera, Baloch et al. 2010; Gaya et al. 2012; 
Divakar et al. 2013; Singh et al. 2013; Otálora et al. 2014; Westberg et al. 2015; Resl et al. 2015) numerous groups are phylogenetically poorly understood and in great need of further study, and the otherwise well-known Caliciaceae is one of these. Caliciaceae forms a group with the nonmazaediate Physciaceae (Wedin et al. 2000, 2002). Although the Caliciaceae and Physciaceae have been suggested to form the suborder Physciineae in the Teloschistales (Miadlikowska et al. 2006; Hibbett et al., 2007; Kirk et al. 2008; Lumbsch and Huhndorf 2010), recent classifications tend to raise the Caliciaceae-Physciaceae group to ordinal level (Gaya et al. 2012) using the name Caliciales. The opinion on the family delimitation varies somewhat. If one prefers treating all Caliciaceae and Physciaceae as one family, the name Physciaceae was proposed for conservation (Wedin and Grube 2002) and should then be used. Recently, however, a two-family concept tends to be preferred (Gaya et al. 2012); Caliciaceae, which includes the non-mazaediate genera with Bacidia-type asci (the Buellia-group of Rambold et al. 1994; e.g. the buellioid genera, Dirinaria and Pyxine; Wedin et al. 2002; Miadlikowska et al. 2006, 2014; Gaya et al. 2012), together with all mazaediate genera in this group, and Physciaceae, which includes taxa belonging to the "Physciagroup" of Rambold et al. (1994), characterized by Lecanoratype asci. Within the Caliciaceae the recognition of two subfamilies has recently been proposed (Gaya et al. 2012): Calicioideae and Buellioideae, but this was very preliminary, based on a small taxon sampling, and it was rather unclear what other taxa should be included in the two groups in addition to the sampled ones.

Tibell (2003) studied the generic delimitations in the mazaediate Caliciaceae based on combined ITS and LSU rDNA data, where many details on the relationships within this group were revealed. Five well-supported clades were identified and informally called the Tholurna-clade, Calicium glaucellum-clade, Calicium hyperelloides-clade, Calicium viride-clade and the Cyphelium tigillare-clade (in the ITS tree, the Acolium-clade was added, making a total of six clades). Perhaps the most interesting results were that both Calicium and Cyphelium in the sense of Tibell (1984) were found to be non-monophyletic. In the ITS tree, Cyphelium inquinans and C. karelicum (the Acolium-clade) formed a group with the monotypic Acroscyphus and Texosporium, and a clade of Calicium adaequatum and Tholurna dissimilis (the Tholurna-clade), but Cyphelium tigillare (type of Cyphelium) and C. notarisii did not belong within that group. Calicium species were further distributed in four of the six clades from the ITS tree. Tibell expanded these investigations in a larger paper on Himalayan Calicium species (Tibell 2006) using ITS rDNA sequences, where he identified four wellsupported clades: clade I, including the Calicium glaucellum and C. hyperelloides clades of Tibell (2003), clade II, including Cyphelium s. str. and three species of Calicium, clade III, including the Calicium viride group (Calicium s. str.), and finally clade IV which includes the Acolium-clade, Tholurna-clade, and an odd Calicium species, C. nobile. These four clades have unclear relationships to each other, and most lack obvious phenotypic characteristics to delimit them.

It is clear that the natural relationships within the mazaediate Caliciaceae remain unresolved, and that several of the mazaediate genera as currently understood are nonmonophyletic and thus unnatural. It is still unclear whether some of these mazaediate groups are more closely related to non-mazaediate groups within the Caliciaceae-Physciaceae clade (Caliciales sensu Gaya et al. 2012).

Adding a temporal dimension to the phylogeny may improve the phylogenetic reconstruction of phenotypic evolution, by detecting causal events or processes in the underlying phylogenetic diversity, and further by establishing a universal time-framework for biological classification that will facilitate studies in comparative evolution (Avise 2009). Divergence time estimation has become increasingly prominent in evolutionary biology, including in the study of several groups of Ascomycota (Amo de Paz et al., 2011; Gueidan et al. 2011; Prieto and Wedin 2013; Beimforde et al. 2014; Divakar et al. 2015; Gaya et al. 2015). Information used to calibrate a phylogenetic tree is obtained from three principal sources: (1) geological events; (2) estimates from independent molecular dating studies; and (3) the fossil record, which normally is the major source of calibration points (Forest 2009). There are, however, several major complications in fungal dating analyses, among which the scarcity of fossils (Berbee and Taylor 2010), the correct interpretation of the fossils available (Kaasalainen et al. 2015), and in particular the unclear assignment of fossils to specific nodes in the phylogeny (Forest 2009), are potential sources of errors.

One fossil belonging to Calicium was described from Baltic amber dating back 55-35 million years ago (Rikkinen 2003). The specimen is embedded in amber and is composed of a single detached ascoma with numerous spores. The ascoma consists of a smooth stalk with a broadly obconical capitulum and a well-developed mazaedium without any visible pruina (something that could have been lost in the preservation process), and with apparently roughly ornamented spores. Although this fossil, in combination with other fossils, was used in several dated phylogenies as a calibration point (Prieto and Wedin 2013; Beimforde et al. 2014) and the assignment to Calicium is not disputed, the exact position within Calicium is uncertain as there is no distinct morphological trait suggesting a clear affinity to any group of extant species.

In the present study, we produce a multilocus phylogeny of the Caliciaceae-Physciaceae clade to generate a hypothesis of the natural relationships in this group, and to test current generic delimitations. We achieve this through phylogenetic analyses using five molecular markers including a broad taxon 
sampling of the Caliciaceae-Physciaceae covering a wide range of groups of mazaedia-producing representatives and non-mazaedioid taxa from the Caliciaceae-clade. We conducted molecular dating analyses in order to understand the temporal framework of the evolution of the group. In this process, we performed different analyses with alternative positions of the Calicium fossil and compared with an analysis carried out with a secondary calibration as a way to evaluate the phylogenetic affinity of the Calicium fossil.

\section{Material and methods}

\section{Taxon sampling}

In this study we focused on the mazaediate members of the Caliciaceae; we also included members of the Physciaceae and the non-mazaediate members of the Caliciaceae (the Buellia-group of Rambold et al. 1994). One member of the Teloschistaceae was used as outgroup (Table 1).

\section{Molecular techniques}

DNA was extracted using DNeasy Plant Mini Kit (Qiagen) according to the manufacturer's instructions. The following five regions were amplified: nuITS, nuLSU, mtSSU, and the protein coding genes $\beta$-tubulin and $\mathrm{mcm} 7$.

We amplified the nuITS with the primers ITS1F (Gardes and Bruns 1993) and ITS4 (White et al. 1990), and the nuLSU with LR0R (Rehner and Samuels 1994), LR3, LR3R, LR6, LR7 (Vilgalys and Hester 1990), PRI1 and PRI2 (Prieto et al. 2010) and nuLSU-155-5' (Döring et al. 2000) in different combinations. We also designed some specific primers for the nuLSU region in order to avoid photobiont amplifications (LSU-JLT-1F: 5'-CTCAGTAACGGCGAGTGAAG-3', LSU-JLT-1R: 5'-TCCGGCACCTTAACCTCAC-3' and LSU-JLT-2R: 5'- CCATCCGAAAACATCTGGA-3'). The mtSSU region was amplified with mtSSU1 and mtSSU3R (Zoller et al. 1999). We used the primers Mcm7-709for and Mcm7-1348rev (Schmitt et al. 2009) for amplification of the $\mathrm{Mcm} 7$ region and in some cases we carried out a nested PCR using $1 \mu \mathrm{l}$ of the PCR product and the internal primers Mcm7CalicF and Mcm7-CalicR (Prieto et al. 2013). The protein coding $\beta$-tubulin was amplified using the primers Bt3-LM and Bt10-LM (Myllys et al. 2001).

PCR amplifications were performed using Illustra ${ }^{\mathrm{TM}}$ Hot Start Mix RTG PCR beads (GE Healthcare, UK) in a $25 \mu \mathrm{l}$ volume, containing 3 to $6 \mu \mathrm{l}$ of diluted genomic DNA, $10 \mu \mathrm{M}$ of each primer and distilled water. Amplifications were performed using the following program: initial denaturation at $95{ }^{\circ} \mathrm{C}$ for $15 \mathrm{~min}$, followed by 35 cycles of $95{ }^{\circ} \mathrm{C}$ for $45 \mathrm{~s}$, 54-56 ${ }^{\circ} \mathrm{C}$ for $50 \mathrm{~s}, 72{ }^{\circ} \mathrm{C}$ for $1 \mathrm{~min}$, followed by a final extension at $72{ }^{\circ} \mathrm{C}$ for $5 \mathrm{~min}$. PCR products were subsequently purified using the enzymatic method Exo-sap-IT (USB Corporation, Santa Clara, California, USA) or when multiple bands were amplified, products were size-fractionated on a $1 \%$ agarose gel run in TBE buffer, stained with GelRed ${ }^{\mathrm{TM}}$ (Biotium Inc.), visualized over a UV trans-illuminator, excised and purified using QIAquick spin columns (Qiagen). The purified PCR products were sequenced using the same amplification primers.

Sequences were assembled and edited using Sequencher v. 4.10.1. (Genes Codes Corporation, Ann Arbor) and deposited in GenBank (Table 1). Subsequently, sequences were aligned manually using MacClade 4.01 (Maddison and Maddison 2001) and translated to amino acids in the protein coding loci. Ambiguous regions (sensu Lutzoni et al. 2000) and introns were delimited manually and excluded from phylogenetic analyses. Additionally, we used Gblocks 0.91b (Castresana 2000) to identify the ambiguous regions. Since the Maximum Likelihood results were very similar between Gblocks and manually constructed matrices we used the latter for the rest of analyses.

\section{Phylogenetic analyses}

Each individual gene region was analysed using maximum likelihood-based inference (ML) as implemented in RAxML ver. 8.1.11 (Stamatakis 2014) with a GTRGAMMA model for tree inference. Bootstraping was performed with a GTRCAT model and 1000 replicates. In order to check for gene-tree incongruence we compared maximum likelihood bootstrap values (ML-BS) between the individual gene trees considering a conflict among clades when a supported clade (bootstrap support $>70 \%$ ) for one marker was contradicted with significant support by another. Because no supported nodes were in conflict, the data were combined into a single concatenated data matrix.

The combined maximum likelihood (ML) analyses were run with 7 distinct partitions (nuITS, nuLSU, mtSSU, first and second codon positions of the $\mathrm{mcm} 7$ and $\beta$-tubulin and the third codon position of the mcm 7 and $\beta$-tubulin), using a GTRGAMMA model of molecular evolution and rate heterogeneity with unlinked parameters and 1000 bootstrap replicates.

To select partitions and its optimal models of nucleotide substitution, we used PartitionFinder version 1.0.1 (Lanfear, 2012) with unlinked branch lengths option and the Akaike Information Criterium (AIC) for model selection. The GTR model (Rodríguez et al. 1990) with an estimated proportion of invariable sites and with a gamma distribution was selected for nuITS, nuLSU and mtSSU, third codon position of the $\beta$ tubulin and first and second codon positions of the $\mathrm{mcm} 7$, while HKY (Hasegawa et al. 1985) and SYM (Zharkikh 1994) with an estimated proportion of invariable sites and 
Table 1 Specimens used for the study, with GenBank accession numbers. Entries for newly obtained sequences are in boldface. Specimen data are given with collection number and location of voucher

\begin{tabular}{|c|c|c|c|c|c|c|}
\hline \multirow[b]{2}{*}{ Species name } & \multirow[b]{2}{*}{ Voucher information } & \multicolumn{2}{|c|}{ GenBank accession number } & \multirow[b]{2}{*}{ nuITS } & \multirow[b]{2}{*}{ nuLSU } & \multirow[b]{2}{*}{$\beta$-tubulin } \\
\hline & & mtSSU & $\mathrm{mcm} 7$ & & & \\
\hline Acolium inquinans & Wedin 6352 (UPS) & AY143404 & JX000161 & AY450583 & AY453639 & KX529023 \\
\hline Acolium karelicum & Hermansson 16472 (UPS) & - & KX529045 & KX512897 & KX512879 & - \\
\hline Acroscyphus sphaerophoroides & Obermayer 6077 (UPS) & KX512984 & KX529029 & KX512898 & - & - \\
\hline Allocalicium adaequatum & Spribille 14143 (UPS) & KX512986 & - & KX512906 & KX512859 & KX528996 \\
\hline Amandinea coniops & Nordin 6113 (UPS) & KX512978 & - & - & KX512865 & KX528998 \\
\hline Amandinea punctata & Wedin 2/3/96 (UPS) & AY143399 & KX529025 & KX512899 & AY340536 & - \\
\hline Anaptychia ciliaris & Wedin 6429 (UPS) & AY 143400 & KX529054 & AY143391 & KX512894 & - \\
\hline Anaptychia runcinata & Santesson 32628 (UPS) & KX512977 & KX529034 & - & - & - \\
\hline Baculifera remensa & Prieto $(\mathrm{S})$ & KX512962 & - & - & KX512881 & - \\
\hline Buellia badia & Westberg 09-079 (S) & KX512963 & - & KX512900 & KX512880 & KX529008 \\
\hline Buellia disciformis & Wedin $6155(\mathrm{BM})$ & JX000116 & JX000152 & AY143392 & JX000082 & - \\
\hline Buellia dispersa & Ryan 21685 (S) & - & KX529035 & - & - & - \\
\hline Buellia elegans & Hansen (S) & KX512993 & - & KX512901 & - & KX528988 \\
\hline Buellia erubescens & Wetmore 95879 (S) & KX512969 & - & KX512902 & KX512874 & KX529004 \\
\hline Buellia frigida & Westberg (S) & KX512992 & - & KX512903 & KX512852 & - \\
\hline Buellia tesserata & Tehler 7323 (S) & - & KX529050 & KX512904 & KX512885 & - \\
\hline Calicium abietinum & Tibell 25061 (UPS) & KX512971 & KX529041 & KX512905 & KX512872 & KX529003 \\
\hline Calicium adspersum & Prieto 3037 (S) & KX512949 & KX529055 & KX512907 & KX512895 & KX529022 \\
\hline Calicium chlorosporum & Tibell 25012 (UPS) & KX512956 & KX529059 & - & KX512892 & - \\
\hline Calicium chlorosporum & Thor 20859 (UPS) & KX512955 & - & - & - & - \\
\hline Calicium corynellum & Prieto (S) & KX512985 & KX529048 & KX512908 & KX512855 & KX528989 \\
\hline Calicium denigratum & Prieto (S) & KX512965 & KX529044 & KX512909 & KX512878 & - \\
\hline Calicium glaucellum & Wedin $8563(\mathrm{~S})$ & KX512980 & KX529032 & KX512910 & KX512864 & - \\
\hline Calicium lecideinum & Prieto $(\mathrm{S})$ & KX512961 & KX529046 & KX512911 & KX512882 & KX529009 \\
\hline Calicium lenticulare & Tibell 23284 (UPS) & KX512979 & KX529033 & KX512912 & - & KX528997 \\
\hline Calicium montanum & van den Boom 23445 (UPS) & - & - & KX529069 & KX512853 & - \\
\hline Calicium nobile 1 & Tibell 21968 (UPS) & KX512988 & KX529060 & KX512913 & KX529070 & - \\
\hline Calicium nobile 2 & Tibell 23396 (UPS) & KX512987 & KX529061 & KX512914 & KX529071 & - \\
\hline Calicium notarisii & Prieto 3007 (S) & KX512960 & KX529047 & KX512915 & KX512883 & KX529011 \\
\hline Calicium pinicola 1 & Lendemer \& Knudsen 14982 (UPS) & KX512972 & KX529040 & KX512916 & KX512871 & KX529015 \\
\hline Calicium pinicola 2 & Thor 19856 (UPS) & KX512991 & KX529066 & KX512917 & KX512887 & KX529014 \\
\hline Calicium quercinum & Tibell 22287 (UPS) & - & - & KX512918 & KX512854 & - \\
\hline Calicium salicinum & Prieto $(\mathrm{S})$ & KX512982 & KX529027 & KX512919 & KX512861 & KX528991 \\
\hline Calicium tigillare & Prieto 3038 (S) & JX000123 & JX000162 & JX000104 & JX000088 & KX529002 \\
\hline Calicium trabinellum & Wedin 8517 (S) & - & KX529026 & KX512920 & KX512858 & KX528995 \\
\hline Calicium trachylioides & Nordin 4002 (UPS) & KX512959 & KX529058 & KX512933 & KX529072 & KX529018 \\
\hline Calicium verrucosum & Tibell 23198 (UPS) & - & KX529030 & - & - & - \\
\hline Calicium viride & Wedin 24/4 2000 & AY584696 & JX000153 & HQ650703 & AY340538 & KX529013 \\
\hline Dermatiscum fallax & Brusse $4944(\mathrm{~S})$ & - & - & KX512921 & KX512866 & - \\
\hline Dimelaena oreina & Lendemer 4193 (S) & KX512976 & KX529036 & KX512922 & KX512867 & KX528999 \\
\hline Dimelaena radiata & Nash 41396 (S) & - & KX529049 & KX512923 & KX512884 & - \\
\hline Diplotomma alboatrum & Prieto 3034 (S) & KX512966 & KX529043 & KX512924 & KX512877 & KX529007 \\
\hline Diplotomma venustum & Westberg 10-176 (S) & KX512968 & - & KX512925 & - & KX529005 \\
\hline Dirinaria applanata & Seaward 109735 (S) & KX512990 & - & KX512926 & KX512856 & - \\
\hline Heterodermia speciosa & Wetmore (S) & KX512975 & KX529037 & KX512927 & KX512868 & KX529000 \\
\hline Heterodermia vulgaris & Frisch 11/Ug1226 (UPS) & KX512989 & - & KX512928 & KX512857 & - \\
\hline
\end{tabular}


Table 1 (continued)

GenBank accession number

\begin{tabular}{|c|c|c|c|c|c|c|}
\hline Species name & Voucher information & mtSSU & $\mathbf{m c m} 7$ & nuITS & nuLSU & $\beta$-tubulin \\
\hline Phaeophyscia ciliata & Prieto $(S)$ & KX512958 & KX529051 & KX512929 & KX512886 & KX529012 \\
\hline Phaeophyscia orbicularis & Prieto $3012(\mathrm{~S})$ & KX512967 & - & KX512930 & KX512876 & - \\
\hline Physcia aipolia & Wedin 6145 (UPS) & AY143406 & KX529052 & KX512931 & AY300857 & KX529021 \\
\hline Physcia tenella & Odelvik \& Hellström 0827 (S) & KX512974 & KX529038 & KX512932 & KX512869 & - \\
\hline Pseudothelomma ocellatum 1 & Tehler 8063 (S) & KX512957 & KX529062 & KX512934 & KX512862 & KX529019 \\
\hline Pseudothelomma ocellatum 2 & Hermansson 18662 (UPS) & KX512952 & KX529063 & KX512935 & KX512891 & KX529020 \\
\hline Pseudothelomma occidentale & Nash 29968 (UPS) & KX529073 & KX529057 & - & - & KX529074 \\
\hline Pyxine coccoes & Prieto $(S)$ & KX512964 & - & KX512936 & - & KX529010 \\
\hline Pyxine sorediata & Wetmore 91254 (S) & KX512973 & KX529039 & KX512937 & KX512870 & KX529001 \\
\hline Tetramelas chloroleuca & Westberg 10-001 (S) & - & - & KX512938 & KX512875 & KX529006 \\
\hline Tetramelas phaeophysciae & Nordin 6896 (UPS) & - & - & KX512939 & - & - \\
\hline Tetramelas pulverulentus & Nordin 6368 (UPS) & KX512983 & - & KX512940 & KX512860 & KX528990 \\
\hline Texosporium sancti-jacobi & Rosentreter \& De Bolt 6514 (UPS) & KX512981 & KX529031 & KX512941 & KX512863 & KX528994 \\
\hline Thelomma mammosum 1 & Tibell 23775 (UPS) & KX512954 & KX529067 & KX512942 & KX512888 & KX529016 \\
\hline Thelomma mammosum 2 & Hernández et al. 2002 (UPS) & KX512953 & KX529065 & KX512943 & KX512851 & KX529017 \\
\hline Thelomma santessonii 1 & Nordin 4011 (UPS) & KX512951 & KX529064 & KX512944 & KX512889 & - \\
\hline Thelomma santessonii 2 & Nash 38262 (UPS) & KX512950 & - & KX512945 & KX512890 & - \\
\hline Tholurna dissimilis & Wedin 6330 (UPS) & AY143407 & KX529053 & AY143397 & KX512893 & KX528992 \\
\hline Tornabea scutellifera & Tibell 23833 (UPS) & KX512970 & KX529042 & KX512946 & KX512873 & - \\
\hline Xanthoria elegans & Odelvik $04532(\mathrm{~S})$ & KX512948 & KX529056 & KX512947 & KX512896 & KX529024 \\
\hline
\end{tabular}

with a gamma distribution were selected for the third codon position of the $\mathrm{mcm} 7$ and for the first and second position of the $\beta$-tubulin, respectively. Bayesian inference was carried out through Markov Chain Monte Carlo (MCMC) sampling, as implemented in MrBayes 3.2.3 (Ronquist et al. 2011). The analyses consisted of two parallel searches, each with four chains, run for $10 \mathrm{M}$ generations, and initiated with random starting trees. The chains were sampled every $1 \mathrm{~K}$ generations from the posterior distribution. A burn-in sample of 25,000 trees was discarded for each run. The remaining 150,000 trees (pooled from both independent runs) were used to assemble a majority rule consensus tree and to estimate branch lengths and Posterior Probabilities (PPs). To determine if the chains had converged, verify if mixing was appropriate, and choose a suitable burn-in, we plotted the log-likelihood values against the time generation with Tracer v.1.5.0 (Rambaut and Drummond 2007). We assumed stationarity of the chains when log-likelihood values reached the same stable equilibrium value for each independent run (Huelsenbeck and Ronquist 2001) and when average standard deviation of split frequencies across runs dropped below 0.01. We also tested the convergence with AWTY program (Nylander et al. 2008; Wilgenbusch et al. 2004). Maximum likelihood, Bayesian analysis and the selection of models were run on the CIPRES Science Gateway v. 3.3 (Miller et al. 2010).

\section{Divergence time estimates and node calibration}

We implemented a Bayesian Markov chain Monte Carlo algorithm for estimating divergence times using data from five gene loci using the BEAST v1.8.2 software package (Drummond et al. 2012). The tree topology and divergence times were estimated simultaneously.

We carried out nine different analyses with different positions of the fossil: A1 (clade A + B), A2 (clade B3), A3 (clade B), A4 (C. corynellum-C. viride), A5 (Calicium glaucellum-C. trabinellum), A6 (C. chlorosporum), A7 (clade B1), A8 (C. nobile-C.chlorosporum) (Fig. 1). For the analysis A9 we used a secondary calibration based on Prieto and Wedin (2013) using Scenario 2 (i.e. without the Alectoria succini fossil, which has recently been reinvestigated by Kaasalainen et al. 2015 and identified as a plant remain), dating the ingroup node (Fig. 1) at 132199 Mya.

In all cases, we had 7 different unlinked partitions (as in the ML analysis), with the GTR + I + G substitution model for each partition except for the third codon position of the $\mathrm{mcm} 7$ for which we selected a KKY + I + G model. We used the uncorrelated lognormal relaxed clock model, which allows rates of molecular evolution to be uncorrelated across the tree. We implemented a Yule tree prior. 


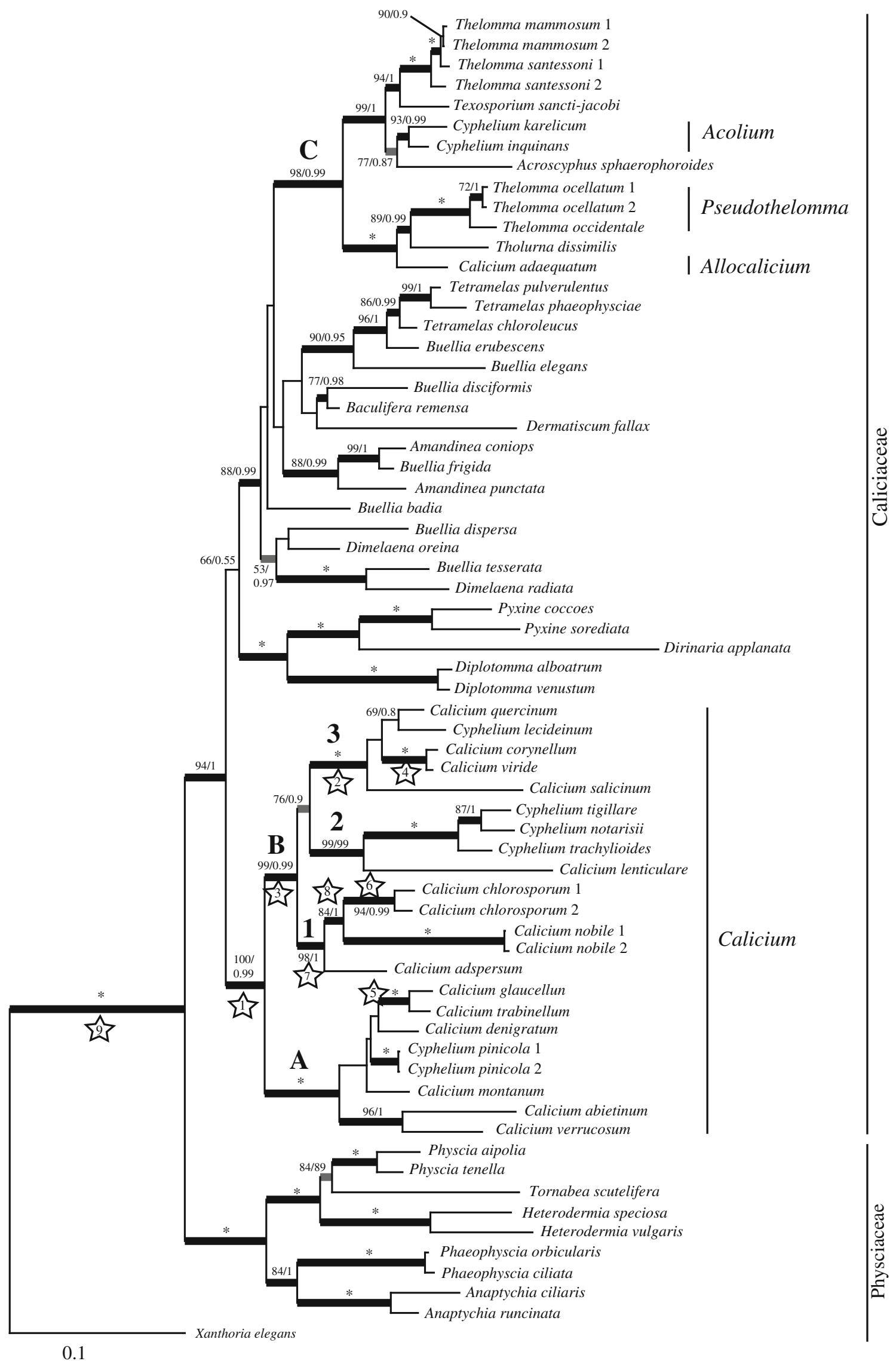


4 Fig. 1 Best tree from RAxML with bootstrap support (ML-BS) and posterior probabilities (PP) obtained in the Bayesian analysis. The support values are ordered as ML-BS/PP. Supported clades by both analyses (ML-BS $\geq 70$, pp. $\geq 0.95$ ) are marked with black thicker branches and with grey thicker branches when the node is only supported by one of the two analyses. An asterisk over a branch indicates that this internode has a ML-BS value and PP of $100 \%$. Numbers within stars indicate the nodes used for fossil calibration and correspond to Scenarios shown in Tab. 2. Newly circumscribed genera are marked in the right part of the figure

We constrained the calibration points (fossil calibrated node) with an exponential distribution dated at 35 Mya with mean $=20$ and offset $=35$. For the secondary calibration (analysis A9) we constrained the ingroup node with a uniform distribution with lower value of 132 Mya and upper value of 199 Mya (based on Scenario 2 from Prieto and Wedin 2013). For each analysis, we ran a first relaxed log-normal clock with default priors to estimate prior distributions to be used in a second analysis that was used to estimate priors for the final analysis. Distributions and parameters used for each analysis are specified in Table 2; priors not specified here were set to the default values.

BEAST analyses were run for 40 million generations, logging parameters and trees every 1000 generations. Convergence, mixing, and effective sample sizes (ESS) of parameters were checked using Tracer v1.5.0 (Rambaut and Drummond 2007). A burn-in of 1000 trees was removed from each analysis. The remaining trees were used to generate a maximum clade credibility tree with TreeAnnotator v1.8.2 (Drummond et al. 2012).

\section{Results and discussion}

A total of 227 sequences were generated for this study (Tab. 1). The combined data set consisted of 66 taxa and 3303 unambiguously aligned sites, 382 for the nuITS, 1021 for the nuLSU, 634 for the mtSSU, 693 for the $\beta$-tubulin and 573 for the $\operatorname{mcm} 7$. The maximum likelihood tree with bootstrap support and posterior probabilities from Bayesian analysis is depicted in Fig. 1. The nine divergence time analyses are compared in Table 2, and discussed below. Divergence time estimates of the analysis A9 (using secondary calibration) are shown in Fig. 2 with $95 \%$ highest posterior density (HPD) for each node.

\section{Phylogenetic results}

This is the most complete taxon sampling conducted in a study of Caliciaceae s. str. to date, and it enables us to draw a number of conclusions and undertake several taxonomic changes that are now supported by a five-marker phylogeny (Fig. 1). The two families Physciaceae and Caliciaceae in the sense of Gaya et al. (2012) are recovered as monophyletic. Although this study does not focus on Physciaceae, the sampled genera in this family are monophyletic and the relationships between them are fully resolved. Among the nonmazaediate Caliciaceae, relationships are not fully resolved, probably due to the fact that Buellia s. lat. is a heterogeneous and species-rich group from which we included comparatively few representatives. Some well-supported results are worth noting. A clade comprising Diplotomma, Dirinaria and Pyxine (also present in Miadlikowska et al. 2014) is resolved. Buellia tesserata and B. dispersa form a group with a nonmonophyletic Dimelaena, which deserves further study. The inclusion of Buellia frigida within Amandinea should also be investigated further. The genus Tetramelas, characterized by the pigmented parts of the spore wall consisting of a thick proper wall and a thin (less than half as thick as the proper wall) irregularly cracked perispore (Nordin 2004), is also monophyletic and closely related to B. elegans (as also suggested by Nordin and Tibell 2005) and B. erubescens.

None of the mazaediate genera within Caliciaceae are monophyletic as currently circumscribed (except monotypic genera). Traditionally, Calicium and Cyphelium have been distinguished mainly by the presence of stalked apothecia in Calicium and sessile or immersed apothecia in Cyphelium. Here we can see that representatives of these two genera are present in the two main clades within Caliciaceae, and none form a monophyletic group, thus demonstrating that presence/ absence of a stalk does not characterize natural groups within this family, a fact already suggested by Tibell (2003). We find it useful to denominate the three clades with mazaediate representatives as clade $\mathrm{A}, \mathrm{B}$ and $\mathrm{C}$, respectively (Fig. 1). Clade A comprises the Calicium glaucellum and Calicium hyperelloides clades of Tibell (2003), but nested within this group is also Cyphelium pinicola. All members of this clade currently classified in Calicium are distinguished by having a thick, hyaline outermost part of the stalk (see e.g. Tibell 1975; p. 79, Fig. 16). Cyphelium pinicola has sessile ascomata, but already Tibell (1969) pointed out its isolated position among the European Cyphelium species, with quite different excipular and spore structure. Cyphelium pinicola is similar, however, in spore ornamentation (irregular cracks or areolae) to the other species of clade A.

Clade A form a well-supported monophyletic group together with clade B. Clade B comprises three distinct subclades. Subclade B1 includes Calicium adspersum, C. chlorosporum and $C$. nobile, which share the presence of a distinctive yellow pruina (rarely brown) on the lower surface of the capitulum and on the mazaedium, and distinctly ornamented spores with spirally arranged ridges. In the previous ITS phylogeny by Tibell (2006), C. nobile grouped at the base of Tibell's Clade IV (the Tholurna dissimilis, Calicium adaequatum, Texosporium, Acroscyphus and the Acoliumclade group). Our results place this species in a more coherent 


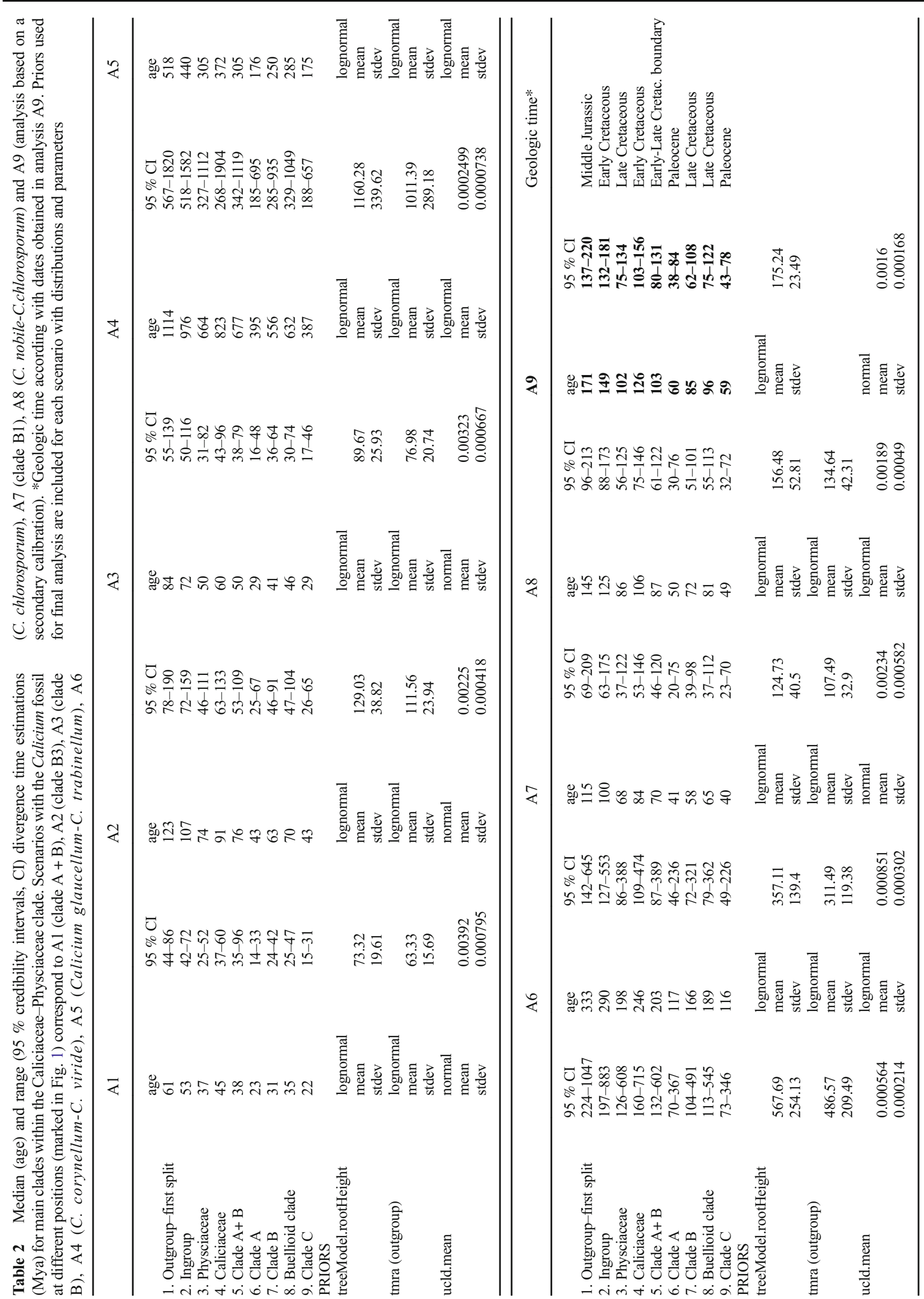




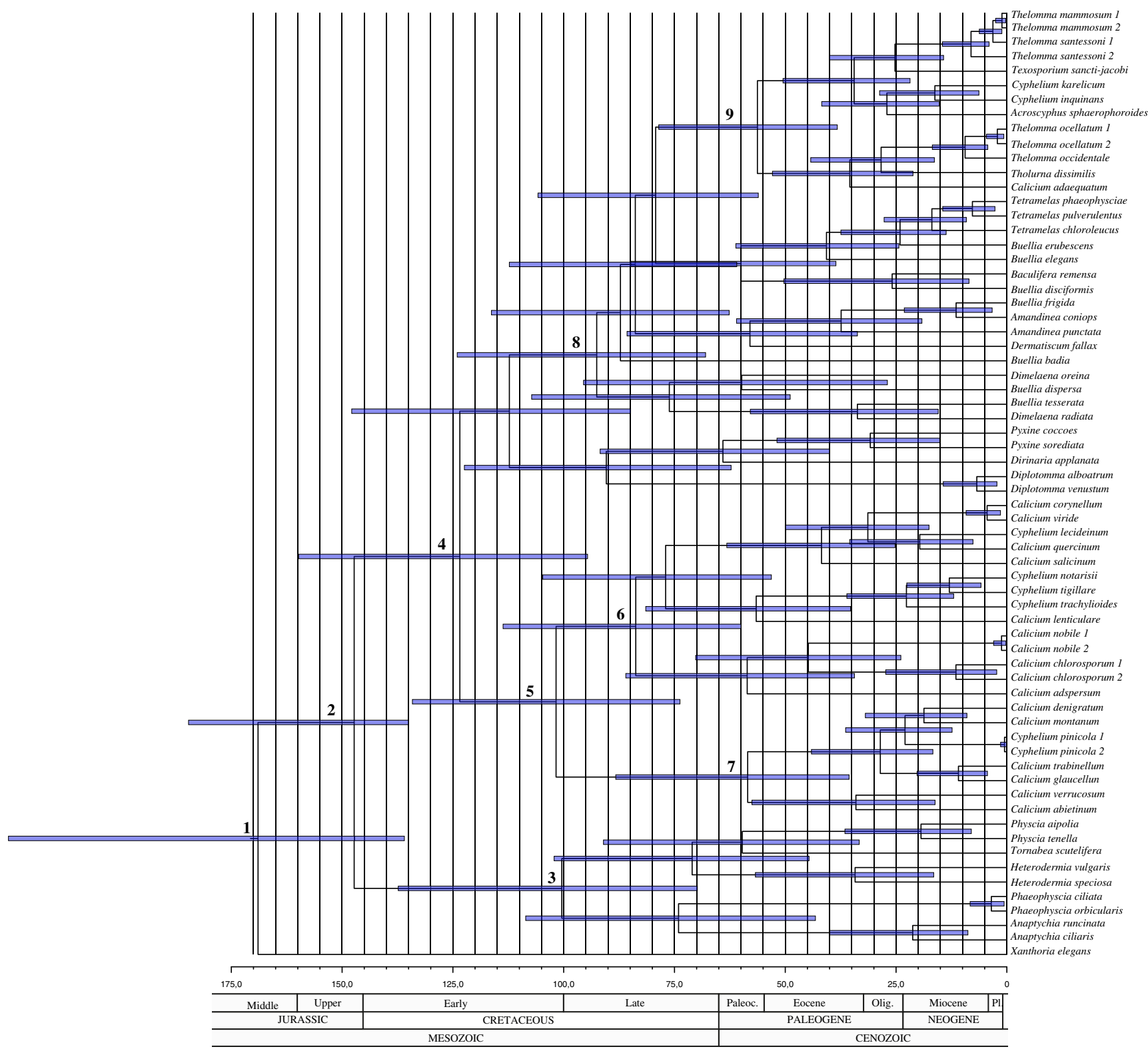

Fig. 2 Maximum clade credibility chronogram for CaliciaceaePhysciaceae. The chronogram is the result from the BEAST analysis using a secondary calibration (analysis A9). Each node represents the

position, which is supported by four single-marker phylogenies ( $\beta$-tubulin missing), and by the concatenated analysis. It should be noted that Calicium nobile has one of the longest branches in the tree, but also that the position and identity was verified by two sequenced samples.

Subclade B2 includes Cyphelium s. str. (type C. tigillare) which is morphologically well-characterized, having immersed apothecia with a very thin excipulum, comparatively small, obovate to pyriform asci, smooth spores, and by growing on dry wood in comparatively exposed situations. Sister to Cyphelium s. str is Calicium lenticulare. Subclades B1 and B2 correspond to Clade II from Tibell (2006), which do not form a monophyletic group in our analysis. median divergence time estimate and bars show their associated $95 \%$ credibility interval. Numbers corresponding to dated groups shown in Table 2 are written above the nodes

Subclade B3 corresponds to Clade III from Tibell (2006) and includes the Calicium viride group (Calicium s. str.). This group is comparatively well characterized morphologically. Calicium viride (the type of Calicium) and the closely related C. corynellum, C. salicinum, and C. quercinum, all have comparatively large and sturdy, stalked ascomata and spores with distinct spiral ornamentation. This well-supported group also includes the non-stalked Cyphelium lecideinum, which shares the very distinct spiral spore ornamentation characteristic for subclade B3.

Clade $\mathrm{C}$ includes the Acolium-clade and the Tholurna-clade of Tibell (2003), and the rather odd Calicium adaequatum. This group corresponds to Tibell's (2006) Clade IV, but contains also 
all Thelomma species included here, although these do not form a monophyletic group. Thelomma mammosum (the type of Thelomma) and T. santessonii are closely related, and together with T. californicum and T. siliceum (not included here) these form a morphologically and chemically well-characterized group of saxicolous species growing in coastal areas, Thelomma s. str. They are closely related to Texosporium sancti-jacobi, and share the presence of immersed sessile ascomata with a laterally reduced exciple. Texosporium, however, is unique in having a distinct spore ornamentation formed by paraphyses that adhere to the surface of the spores (Tibell and von Hofsten 1968). Texosporium also has a unique ecology among mazaediate lichens, growing on dung, soil and detritus in grassland soil crust communities (McCune and Rosentreter 1992).

Thelomma ocellatum and T. occidentale are closely related species, which are morphologically and chemically very similar (Tibell 1976) and grow on dry wood in exposed locations. Thus, they are quite different from Thelomma s. str., and group together with Calicium adaequatum and Tholurna dissimilis. Tholurna dissimilis produces radially protruding podetia, which carries apically situated ascomata. Tibell (1984) noted that Tholurna was not similar to the other species with podetia (Acroscyphus) in several characteristics, which is supported by our phylogeny. Calicium adaequatum is the only species with stalked apothecia within this clade, and Tibell (2003) commented on that $C$. adaequatum shared the presence of a campanulate capitulum with Tholurna, and a very similar strong surface ornamentation of the spores. Both species grow on twigs, and have actually a rather similar general appearance, forming small clumps of podetia or stalked ascomata. Several independent investigations have now suggested that Calicium adaequatum and Tholurna form a group, and we can here conclude that Thelomma ocellatum and T. occidentale also belong to this group. It is difficult to argue for treating these four rather distinct taxa (Calicium adaequatum, Tholurna, and Thelomma ocellatum $+T$. occidentale) in one genus as the two first share few obvious unique morphological traits with the two latter. Including $C$. adaequatum in Tholurna is not an option as this genus would become paraphyletic. We thus suggest describing new genera for both C. adaequatum, and for the Thelomma ocellatum + T. occidentale group (see below).

Cyphelium sensu Tibell (1984) is very heterogeneous, with species ending up in four places in the tree. Already Tibell (1971) remarked that Cyphelium probably was heterogeneous, which was further supported by the early SSU rDNA based phylogeny by Wedin et al. (2000). Tibell suggested (Tibell 2003: 1415) that Cyphelium inquinans and C. karelicum should be recognized as a separate genus, for which the name Acolium (Ach.) S. Gray is available, but this has not been taken up. The recognition of Acolium is however clearly supported in our analysis. Acolium is a small group of species growing on wood or bark, and are further characterized by a dark excipulum that is strongly thickened at the base and ornamented spores. They have a distinct greyish-brownish thallus, sessile to somewhat immersed ascomata, and a grey pruina on the rim of the excipulum. Acolium forms a group with Thelomma s. str. and Texosporium. The core group of Cyphelium (C. tigillare, C. trachylioides, and C. notarisii) is a group of morphologically similar and closely related species growing on dry and exposed wood, which are characterized by immersed apothecia with a very thin excipulum and smooth spores. Cyphelium s. str. is nested within the majority of Calicium, in clade $\mathrm{A}+\mathrm{B}$, as are Cyphelium pinicola and C. lecideinum. Cyphelium lucidum is not included in our multigene phylogeny, but we have added the ITS sequences present in GenBank (EF551163, EF551164 and EF551165) to our ITS alignment and conducted a maximum likelihood analysis in order to check the position of the species. The resulting tree shows that C. lucidum is likely to be closely related to Calicium adspersum in Clade B1 although without support (results not shown).

Although there are some morphologically quite distinct subgroups within Calicium that could be given generic rank, we would still be left with a number of poorly characterized, potentially monotypic genera needing names. Accepting Cyphelium in any sense would make Calicium paraphyletic. We instead suggest including Cyphelium s. str. (the Cyphelium tigillare-group), Cyphelium lecideinum, Cyphelium pinicola, and Cyphelium lucidum, in Calicium. This results in a phylogenetically distinct Calicium that, however, is rather difficult to characterize morphologically. We finally note that the subfamily classification proposed by Gaya et al. (2012) becomes superfluous, as the Calicioideae now corresponds to the genus Calicium only.

\section{Divergence time estimates}

The phylogenetic assignment of fossils is frequently difficult as these may lack diagnostic characteristics for living clades, because the fossils are genuinely primitive or because derived characteristics are not preserved in the fossil (already noted by Hennig 1981). The additional problems of non-monophyletic extant taxa and parallel evolution of traits clearly also frequently prevents an unambiguous fossil assignment, as in the case present here. Although the fossil clearly belongs to Calicium (see Table 3 for a comparison with similar mazaediate genera), the relationship with a specific group within Calicium is not possible to infer based on the few visible characters that the fossil possesses. Thus, we instead wanted to explore the phylogenetic placements of the fossil, by comparing different alternative and arbitrary positions with a scenario based on a secondary calibration.

We obtained very different time estimates when using different alternative fossil positions and when using a secondary calibration. The credibility intervals of the alternative 


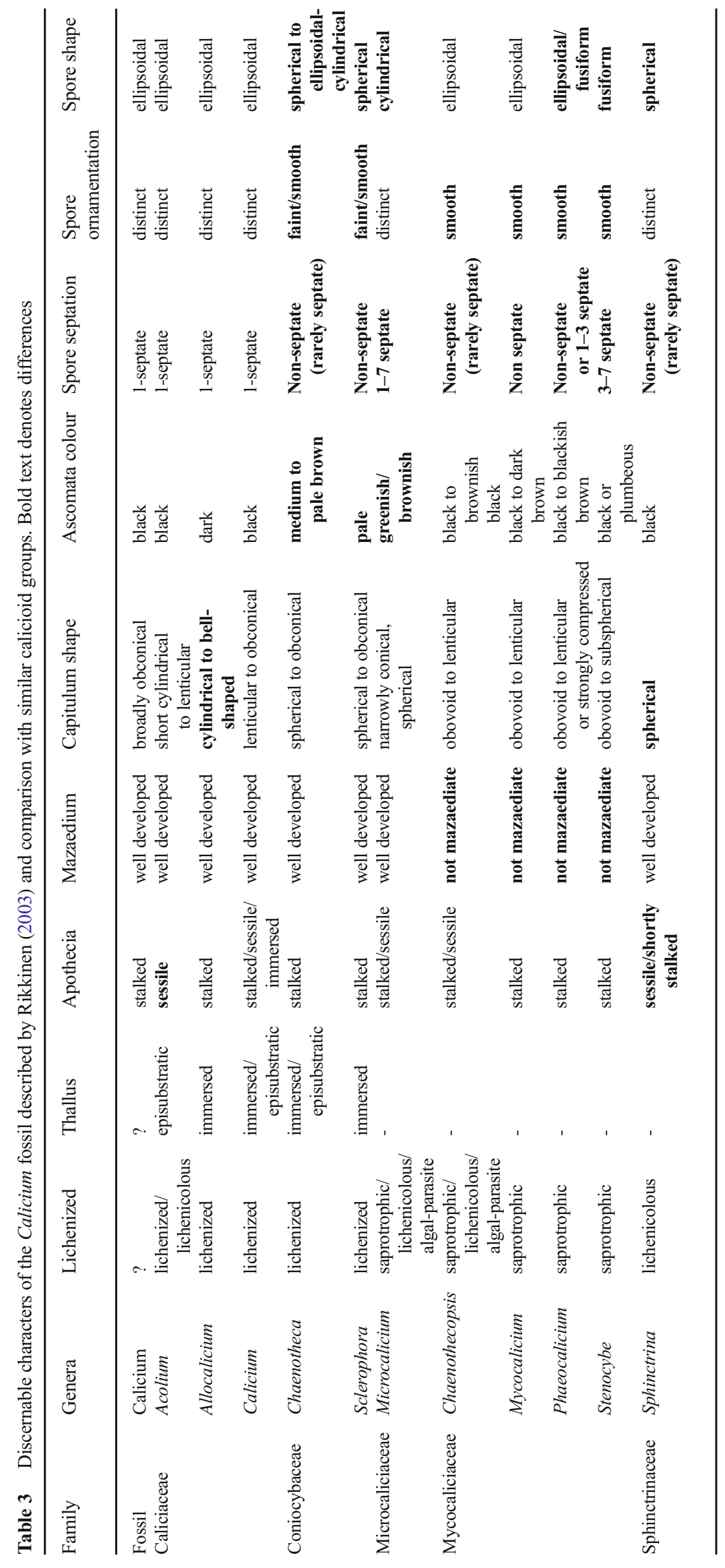


estimates were in many instances non-overlapping (see Tab. 2 for selected nodes). The results obtained placing the fossil at the base of clade $A+B(A 1)$, clade B3 (A2), clade B (A3) and clade B1 (A7) resulted in younger ages (Tab. 2) than the analysis with the fossil placed in more terminal nodes as A4, A5 and A6. All these analyses differ considerably from the results of other dating studies (Prieto and Wedin 2013; Beimforde et al. 2014) which obtained much older or younger ages for the crown of Caliciales (166 Mya in Scenario 2 from Prieto and Wedin 2013 and ca. 160 Mya in Beimforde et al. 2014) and from those obtained based on a secondary calibration (our analysis A9). Analysis A8 is the most similar to the secondary calibration analysis suggesting that the most likely placement of the fossil is close to a terminal node and thus, a basal placement in the Calicium clade can likely be rejected.

As the secondary calibration analysis is based on a previous study with a robust fossil record using five fossil calibration points (Prieto and Wedin 2013), we believe this analysis is more reliable than any estimate based on one single fossil only, thus justifying basing our discussion on the chronogram resulting from this analysis (Fig. 2). In our dating analysis based on a secondary calibration the split between the Caliciales sensu Gaya et al. 2012 (the CaliciaceaePhysciaceae clade) and the Teloschistales took place in the Middle Jurassic, around 171 Mya. The age for the Physciaceae crown group in A9 is estimated at 102 Mya, and the Caliciaceae crown group at 126 Mya, thus comparable to the estimate in Prieto and Wedin (2013) and estimates produced by independent studies in other lichen families (Amo de Paz et al., 2011; Beimforde et al. 2014; Divakar et al. 2015; Gaya et al. 2015). The age of the $\mathrm{A}+\mathrm{B}$ clade (main mazaediate clade) is estimated at $103 \mathrm{Mya}$ (95\% HPD =80-131 Mya) with two diversification events within the group; a first event at 85 Mya giving rise to clade $\mathrm{B}$, and a second event at 60 Mya giving rise to clade $\mathrm{A}$. This last event coincides with the time of appearance of the mazaediate taxa included in the Buellioi d clade (clade C, 59 Mya).

The diversification of the Physciaceae during the Late Cretaceous (102 Mya) in our secondary calibration analysis (A9) is congruent with diversification dates for other lichen families as Teloschistaceae (98 Mya, Gaya et al. 2015) and Parmeliaceae (109 Mya, Amo de Paz et al., 2011) while the diversification of the Caliciaceae took place somewhat earlier, during the Early Cretaceous (126 Mya). The mazaediate clades arose during two different periods, at the Early-Late Cretaceous boundary and in the Paleocene. The first event is close to the Cretaceous thermal maximum (89-112 Mya) where the diversification of the family Teloschistaceae was recently suggested to have taken place (Gaya et al. 2015). The second event took place close to the Paleocene-Eocene Thermal Maximum, 55.8 million years ago (Röhl et al. 2000).
In this latter period two independent events took place, a diversification episode within the Calicium clade coincident with an independent origin of the mazaediate clade within the Buellia-clade (clade $\mathrm{C}$ ).

The main diversification events of mazaediate taxa took place during the Paleocene, Eocene and Oligocene as it has been reported for taxa within the lichen family Parmeliaceae (Divakar et al. 2015). The parallel, independent gains of the mazaedium in the history of the Ascomycota have already been demonstrated (Prieto et al. 2013). The appearance of other mazaediate groups is congruent with the diversification events found here. For example the Coniocybomycetes crown is dated at 106 Mya and the Microcaliciales at 40 Mya (Prieto and Wedin 2013). Thus, it is probable that around this time climatic events on earth could have favored the independent appearance of these groups of taxa characterized by the presence of a mazaedium. What external factors could have promoted the appearance and diversification of mazaediate groups? As most of the extant species are epiphytes, growing on trunks or decorticated stumps of both conifers and deciduous trees, one possible explanation could be the appearance and diversification of conifers and angiosperms in the Early Mesozoic and Early Cenozoic respectively (Leslie et al. 2012; Magallón et al. 2015; Silvestro et al. 2015) and the change of the landscape this must have produced.

We conclude that utilizing a fossil with a poorly understood taxonomic affinity within the group under study is clearly problematic. One way to improve the accuracy of molecular time estimates is to use multiple fossil constraints (Graur and Martin 2004; Hedges and Kumar 2004; Rutschmann et al., 2007; Sauquet et al. 2012). However, the very small number of well-preserved and identifiable lichen fossils is a limiting factor in dating studies, and in our particular case there are currently no more available fossils. Another approximation is to use secondary calibrations, obtained from previous studies (Graur and Martin 2004; Sauquet et al. 2012). In this study we conclude that using such previously obtained dates gives us results that are comparable with other dating studies, whereas assigning the single relevant fossil to arbitrary placements results in strongly deviant dates. By comparing the inferred divergence dates with widely accepted dates (usually based on a robust fossil record) we here provide insight into the role of unreliable fossils in date estimates. Although this could be seen as a circular argument, the use of secondary calibrations can in reality serve as evaluation of the phylogenetic affinity of a fossil. In our case we can discard several alternative placements investigated, suggesting that the fossil is likely to be member of a younger clade as the C. chlorosporum- $C$. nobile and thus discarding its basal placement. This result will contribute to future dating studies, since it provides a good guide about which taxa to include in such studies and where to place the fossil best. 


\section{Taxonomy}

Acolium (Ach.) Gray, Nat. Arr. Brit. Pl. I: 482 (1821).

Type species: Calicium tympanellum Ach. (lectotype, designated by Tibell 1984) = Acolium inquinans $(\mathrm{Sm}$.) A. Massal.

Ca 5 species: Acolium chloroconium Tuck., A. inquinans (Sm.) A. Massal., A. karelicum (Vain.) M. Prieto and Wedin, A. marcianum (B. de Lesd.) M. Prieto and Wedin, A. sessile (Pers.) Arnold.

New combinations in Acolium:

Acolium karelicum (Vain.) M. Prieto and Wedin, comb. nov. (MB 817532) Basionym: Cyphelium lucidum var. karelicum Vain., Acta Soc. Fauna Fl. Fenn. 57(I): 20 (1927).

Acolium marcianum (B. de Lesd.) M. Prieto and Wedin, comb. nov. (MB 817533) Basionym: Cyphelium marcianum B. de Lesd., Bull. Soc. Bot. France 55: 420 (1908).

Comments: This is a small group of former Cyphelium species predominantly growing on bark or wood. Acolium is characterized by a dark excipulum that is strongly thickened at the base. Species placed here have a distinct grey-brown thallus (or are lichenicolous and do not form an independent thallus), they have sessile to somewhat immersed ascomata, and several have also a grey pruina on the rim of the exipulum. Although not investigated here, Acolium chloroconium is very similar to and presumably closely related to A. inquinans (Tibell and Ryan 2004) and is best placed here as Cyphelium is no longer available. Acolium sessile and A. marcianum, both lichenicolous on species of Pertusaria s. lat. and not investigated molecularly by us, also seem best placed here as they share the basally thickened excipulum with the other species. The placement of these three species needs confirmation from sequenced material.

Tibell (1984) designated Calicium tympanellum (a synonym of Cyphelium inquinans) as type species of Acolium. Both the other species originally included by Acharius (1808) in Calicium [unranked] Acolium (C. turbinatum and C. stigonellum) are synonyms of Sphinctrina turbinata. Several authors (Fink 1911; Clements and Shear 1931) assumed that the rankless subdivision Acolium was published in Acharius (1810), which make the type species selected by Fink and Clements and Shear not correctly designated.

Acroscyphus Lév., Annls. Sci. Nat., sér. 3 5: 262 (1846).

Type species: Acroscyphus sphaerophoroides Lév.

Comments: Acroscyphus is a distinct monotypic genus which is easily distinguished from the sister group Acolium by the dactyliform, fruticose thallus and the laterally reduced excipulum.

Calicium Pers., in Romer and Usteri, Ann. Bot. 7: 20 (1794).

Type species: Calicium viride Pers. (lectotype, designated by Fink, Contr. U.S. Nat. Herb. 14(1): 46, 1910).
At least 34 species: C. abietinum Pers., C. adspersum Pers., C. carolinianum (Tuck.) M. Prieto and Wedin, C. chlorosporum F. Wilson, C. constrictum Tibell, C. corynellum (Ach.) Ach., C. denigratum (Vain.) Tibell, C. glaucellum Ach., C. hyperelloides Nyl., C. indicum Tibell, C. laevigatum Tibell, C. lecideinum (Nyl.) M. Prieto and Wedin, C. lenticulare Ach., C. leucochlorum Tuck., C. lucidum (Th.Fr.) M. Prieto and Wedin, C. montanum Tibell, C. nobile Tibell, C. notarisii (Tul.) M. Prieto and Wedin, C. parvum Tibell, C. pinastri Tibell, C. pinicola (Tibell) M. Prieto and Wedin, C. pyriforme Tibell, C. quercinum Pers., C. robustellum Nyl., C. salicinum Pers., C. sequoiae Williams and Tibell, C. tenuisporum Tibell, Calicium tigillare (Ach.) Pers., C. trabinellum Ach., C. trachylioides (Nyl. ex Branth and Rostr.) M. Prieto and Wedin, C. tricolor F. Wilson, C. verrucosum Tibell, C. victorianum (F. Wilson) Tibell, C. viride Pers.

New combinations in Calicium:

Calicium carolinianum (Tuck.) M. Prieto and Wedin, comb. nov. (MB 817549) Basionym: Acolium carolinianum Tuck., Gen. lich. (Amherst): 237 (1872).

Calicium lecideinum (Nyl.) M. Prieto and Wedin, comb. nov. (MB 817534) Basionym: Trachylia lecideina Nyl., Mem. Soc. Sci. Nat. Cherbourg 3: 199 (1855).

Calicium lucidum (Th.Fr.) M. Prieto and Wedin, comb. nov. (MB 817535) Basionym: Trachylia lucida Th.Fr.., Öfvers. K. VetenskAkad. Förh. 12: 18 (1855).

Calicium notarisii (Tul.) M. Prieto and Wedin, comb. nov. (MB 817538) Basionym: Acolium notarisii Tul., Ann. Sci. Nat., Bot., sér. 3 17: 81 (1852).

Calicium pinicola (Tibell) M. Prieto and Wedin, comb. nov. (MB 817536) Basionym: Cyphelium pinicola Tibell, Svensk Bot. Tidskr. 63: 477 (1969).

Calicium trachylioides (Nyl. ex Branth and Rostr.) M. Prieto and Wedin, comb. nov. (MB 817537) Basionym: Spilomium trachylioides Nyl. ex Branth and Rostr., Lichenes Daniae: 141 (1869).

Comments: Calicium in this emended version includes both species with stalked (Calicium in the traditional sense) and sessile or immersed ascomata. The stalked species differ from Allocalicium in the shape of the capitulum and the colour of the stalk. Although phylogenetically very distinct, we do not currently know of any morphological or chemical character that is unique for Calicium in our sense, and here, more work is needed. Cyphelium Ach. (type Lichen tigillaris Ach.) is a new synonym to Calicium. For more synonyms, see Tibell (1984). Calicium carolinianum, usually placed in Thelomma, was not considered closely related to Thelomma s. str. nor to the T. ocellatum group (Pseudothelomma, see below) by Tibell (1976), and we agree with him. Tibell (1976, 1984), however, points out similarities between $T$. carolinianum and species placed by him in Calicium and Cyphelium, and 
we suggest placing it in Calicium until molecular investigations can clarify its position.

Texosporium Nádv., in Tibell and Hofsten, Mycologia 60: 557 (1968).

Type species: Acolium sancti-jacobi Tuck.

Comments: Texosporium grows on dung, soil and detritus in grassland soil crust communities, and differs from the related Thelomma by the ecology and the very distinct spore ornamentation formed by paraphyses that adhere to the surface of the spores (Tibell and von Hofsten 1968).

Thelomma A. Massal., Atti Reale Ist. Veneto Sci. Lett. Arti, ser 3, 5: 268 (1860).

Type species: Cyphelium mammosum Hepp, in Hartung 1857: 147 (1857).

Ca 5 species: T. brunneum (W.A. Weber) M. Prieto and Wedin, T. californicum (Tuck.) Tibell, T. mammosum (Hepp) A. Massal., T. santessonii Tibell, T. siliceum (Fée) Tibell.

New combination in Thelomma:

Thelomma brunneum (W.A. Weber) M. Prieto and Wedin, comb. nov. (MB 817539) Basionym: Cyphelium brunneum W.A. Weber, Bryologist 70: 199 (1967).

Comments: Thelomma differs from the related Texosporium by growing on rocks in Mediterranean areas, and by lacking the distinctive spore ornamentation that characterizes Texosporium. The newly described Pseudothelomma differs in having a thin cortex, lacking the granular crystals that intersperse the usually thick cortex in Thelomma, and in the ecology as Pseudothelomma grows on decorticated wood. The generic placement of Thelomma brunneum needs verification from sequenced material. Thelomma brunneum was hitherto placed in Cyphelium, but as this genus is no longer available, Thelomma seems the best place as it share the ecology (growing on rocks in Mediterranean areas of North America).

Tholurna Norman, Flora (Regensburg) 44: 409 (1861).

Type species: Tholurna dissimilis (Norman) Norman.

Comments: Tholurna is a rare monospecific genus characterized by its cushion-like colonies, formed of dense clustered podetia carrying one ascoma each apically. The capitulum is campanulate, and the spores have a very distinctive ornamentation of spirally arranged ridges, two characters similar to Allocalicium.

\section{New genera}

Allocalicium M. Prieto and Wedin gen. nov. (MB 817540).

Type species: Allocalicium adaequatum (Nyl.) M. Prieto and Wedin.

Diagnosis: thallus immersed. Ascomata with olive brown stalks forming small clumps; capitulum campanulate and dark; spores 1-septate with a distinct ornamentation of spirally arranged ridges.
Etymology: Allo-, greek prefix meaning different or strange, which denotes a difference with Calicium while indicating an overall morphological similarity.

Description:

Thallus immersed. Ascomata distinctly stalked, $8-10$ times as high as the diameter of the stalk, without pruina and with dark capitulum and pale grey to olive brown stalk. Capitulum cylindrical to distinctly bell-shaped. Excipulum 20-35 $\mu \mathrm{m}$ thick, with a distinct thickening in the upper part. Outermost part of the excipulum brown, consisting of isodiametric medium brown cells, 3-5 um diam. Inner part of excipulum 10$17 \mu \mathrm{m}$ thick, consisting of intertwined hyphae with swollen walls. Hypothecium medium brown, up to $40 \mu \mathrm{m}$ high, consisting of intertwined, brown, thin walled hyphae. Stalk rather short to long, inner part of periclinally arranged but intertwined hyphae of thick walls; outermost layer medium brown with periclinally arranged brown hyphae. Stalk and excipulum I+ dark blue. Asci cylindrical with uniseriately or sometimes biseriately arranged spores. Spores 1-septate, 9 $11 \times 4.5-5.5 \mu \mathrm{m}$, with a distinct ornamentation of spirally arranged ridges. Habitat: on thin branches of Alnus incana, Populus and Salix along streams and in well-lit situations in swampy areas with high humidity.

New combinations in Allocalicium:

Allocalicium adaequatum (Nyl.) M. Prieto and Wedin, comb. nov. (MB 817541) Basionym: Calicium adaequatum Nyl., Flora, Regensburg 52: 409 (1869).

Comments: Allocalicium is distinguished from the stalked species in the unrelated Calicium by the pale stalks, the dark, cylindrical to distinctly bell-shaped capitulum, and the ecology. As already commented on, Allocalicium shares the campanulate form of the capitulum with the closely related Tholurna, and they both have very similar spore ornamentation.

Pseudothelomma M. Prieto and Wedin gen. nov. (MB 817542).

Type species: Pseudothelomma ocellatum (Körb.) M. Prieto and Wedin.

Diagnosis: thallus crustose, grey, with a thin cortex that lacks crystals. Ascomata immersed in verrucae, flat, sometimes with a green-(yellow) pruina on the mazaedia; exciple laterally thin; spores 1-septate. Chemical compounds: occasionally usnic acid (in thallus) and epanorin and rhizocarpic acid in the hymenium and mazaedium.

Etymology: the name of this new genus is based on the resemblance to Thelomma where the species have been included until now.

Description:

Thallus crustose, well developed, verrucose or subareolate, grey; one species with globular, short-stalked isidia in black patches on the thallus surface. Cortex thin, without granular crystals. Ascomata immersed in verrucae. Mazaedium black, flat, sometimes with a greenish or greenish-yellow pruina. 
Excipulum not sclerotized, poorly developed laterally. Hypothecium blackish brown. Asci cylindrical, with uniseriately arranged spores, 1-septate, blackish-brown, constricted at the septum, with a slightly uneven surface. Chemistry: thallus $\mathrm{K}-, \mathrm{C}-, \mathrm{KC}-, \mathrm{PD}-$, medulla I- or I+ dark blue; occasionally usnic acid in the thallus, and epanorin and rhizocarpic acid in the hymenium and mazaedium. Habitat: on exposed dry lignum, particularly on wooden posts.

2 species: Pseudothelomma ocellatum (Körb.) M. Prieto and Wedin, P. occidentale (Herre) M. Prieto and Wedin.

New combinations in Pseudothelomma:

Pseudothelomma occidentale (Herre) M. Prieto and Wedin, comb. nov. (MB 817544) Basionym: Cyphelium occidentale Herre, Proc. Wash. Acad. Sci. 12: 62 (1910).

Pseudothelomma ocellatum (Körb.) M. Prieto and Wedin, comb. nov. (MB 817543) Basionym: Acolium ocellatum Körb., Parerga lichenol. 3: 285 (1861).

Comments: Pseudothelomma is a small, distinct group of species with immersed ascomata, growing on dry and exposed lignum. It differs from the otherwise similar Acolium by having a thin and non-sclerotized excipulum. It further differs from the likewise similar Thelomma by the ecology, and the thin, crystal-free cortex.

\section{Key to mazaedium-producing Caliciaceae sensu Prieto \& Wedin.}

1 Fruticose lichens, forming proper podetia of thalline origin. 2

1 Crustose lichens, with stalked, sessile or immersed apothecia.

2 (1) Thallus stout, sparingly branched, pale greyish, ascomata immersed in branch-tips. Spores 2-celled with constricted septum, smooth. On rocks or epiphytic.....................Acroscyphus sphaerophoroides 2 Thallus of radially protruding dark grey to brownish podetia, ascomata campanulate on apices of finger-like protrusions. Epiphytic on twigs...........Tholurna dissimilis 3 (1) Apothecia stalked. ...4

3 Apothecia sessile or immersed........................................... 4 (3) Apothecia with a pale grey to pale olive stalk and a dark, cylindrical to campanulate capitulum. Epiphytic on twigs or thin branches................Allocalicium adaequatum 4 Apothecia not with a pale stalk together with a dark, campanulate capitulum. .Calicium pro parte 5 (3) Spores smooth, apothecia immersed with a very thin excipulum (section). On dry wood or (rarely) bark.....................Calicium ("Cyphelium" tigillare-group) 5 Spores with a \pm distinct ornamentation, apothecia immersed or sessile with a distinct excipulum which is thick, at least at the base. On bark, wood or rocks.
6 (5) Spore ornamentation very distinct, formed by paraphyses that adhere to the surface of the spores. On dung, detritus or soil in grassland and soil crust communities. Texosporium sancti-jacobi 6 Spore ornamentation made up by ridges or surface cracks. On rock, bark, wood, or lichenicolous.....................7 7 (6) On rock (Thelomma californicum occasionally on wood) ...8 7 On bark or wood, or lichenicolous on Pertusaria ..........9 8 (7) Apothecia immersed in thallus verrucae......Thelomma 8 Apothecia sessile. Calicium lecideinum 9 (7) Apothecia sessile to somewhat immersed, with a grey pruina on the rim of the excipulum, and a dark excipulum that is strongly thickened at the base (section). Thallus distinct, greyish-brownish. On wood or bark, or lichenicolous on Pertusaria spp.. Acolium

9 Apothecia and thallus varying.. 10

10 (9) On dry and exposed wood, with immersed apothecia.. . .11

10 On wood or bark, apothecia sessile.

.Calicium spp. (former Cyphelium spp)

11 (10) Thallus verrucose, greyish, excipulum thin and hyaline throughout, asci cylindrical..... Pseudothelomma 11 Thallus smooth, areolate, dull reddish-brown, exipulum thick and \pm sclerotized at the base, asci pyriform Calicium carolinianum

Acknowledgments This research was supported by grants from the Swedish Research Council (VR 621-2009-5372 and VR 621-2012-3990) to MW. We are grateful for skilful lab assistance from the Molecular Systematics Laboratory at the Swedish Museum of Natural History. Kind assistance during fieldwork was provided by Janolov Hermansson. Ibai Olariaga and Martin Westberg are thanked for comments on the manuscript. This paper is dedicated to Leif Tibell for his life-long, groundbreaking work on mazaediate lichens.

Open Access This article is distributed under the terms of the Creative Commons Attribution 4.0 International License (http:// creativecommons.org/licenses/by/4.0/), which permits unrestricted use, distribution, and reproduction in any medium, provided you give appropriate credit to the original author(s) and the source, provide a link to the Creative Commons license, and indicate if changes were made.

\section{References}

Acharius E (1808) Förteckning på de i Sverige växande arter af lafvarnes familj. K Vetensk Acad Nya Handl 1808:259-283

Acharius E (1810) Lichenographia universalis. Gottingae, 696 pp

Amo de Paz G, Cubas P, Divakar PK, Lumbsch HT, Crespo A (2011) Origin and diversification of major clades in parmelioid lichens (Parmeliaceae, Ascomycota) during the Paleogene inferred by Bayesian analysis. PLoS One 6:e28161 
Avise JC (2009) Timetrees: Beyond cladograms, phenograms, and phylograms. In: Hedges B, Kumar S (eds) Timetrees of Life. Oxford University Press, Oxford, UK, pp. 19-25

Baloch E, Lücking R, Lumbsch HT, Wedin M (2010) Major clades and phylogenetic relationships between lichenized and non-lichenized lineages in Ostropales. Taxon 59:1483-1494

Beimforde C, Feldberg K, Nylinder S, Rikkinen J, Tuovila H, Dörfelt H, Gube M, Jackson DJ, Reitner J, Seyfullah LJ, Schmidt AR (2014) Estimating the phanerozoic history of the Ascomycota lineages: Combining fossil and molecular data. Mol Phylogenet Evol 77: 307-319

Berbee ML, Taylor JW (2010) Dating the molecular clock in fungi- how close are we? Fungal Biology Rev 24:1-16

Castresana J (2000) Selection of conserved blocks from multiple alignments for their use in phylogenetic analysis. Mol Biol Evol 17:540 552

Clements FE, Shear CL (1931) The genera of Fungi. Wilson M W, New York, $456 \mathrm{pp}$

Divakar PK, Crespo A, Núñez-Zapata J, Flakus A, Sipman HJM, Elix JA, Lumbsch HT (2013) A molecular perspective on generic concepts in the Hypotrachyna clade (Parmeliaceae, Ascomycota). Phytotaxa 132:21-38

Divakar PK, Crespo A, Wedin M, Leavitt SD, Hawksworth DL, Myllys L, McCune B, Randlane T, Bjerke JW, Ohmura Y, Schmitt I, Boluda CG, Alors D, Roca-Valiente B, Del-Prado R, Ruibal C, Buaruang K,, Núñez-Zapata J, Amo de Paz G, Rico VJ, Molina MC, Elix JA, Esslinger TL, Tronstad IK, Lindgren H, Ertz D, Gueidan C, Saag L, Mark K, Singh G, Dal Grande F, Parnmen S, Beck A, Benatti MN, Blanchon D, Candan M, Clerc P, Goward T, Grube M, Hodkinson BP, Hur JS, Kantvilas G, Kirika PM, Lendemer J, Mattsson JE, Messuti MI, Miadlikowska J, Nelsen M, Ohlson JI, Pérez-Ortega S, Saag A, Sipman HJ, Sohrabi M, Thell A, Thor G, Truong C, Yahr R, Upreti DK, Cubas P, Lumbsch HT (2015) Evolution of complex symbiotic relationships in a morphologically derived family of lichen-forming fungi. New Phytol 208:1217-1226. doi: 10.1111 /nph.13553.

Döring H, Clerc P, Grube M, Wedin M (2000) Mycobiont-specific PCR primers for the amplification of nuclear ITS and LSU rDNA from lichenized ascomycetes. Lichenologist 32:200-204

Drummond AJ, Suchard MA, Xie D, Rambaut A (2012) Bayesian phylogenetics with BEAUti and the BEAST 1.7. Mol Biol Evol 29: 1969-1973

Fink B (1911) The nature and classification of lichens, I. Mycologia 3: 231-269

Forest F (2009) Calibrating the Tree of Life: fossils, molecules and evolutionary timescales. Ann Bot 104:789-794

Gardes M, Bruns TD (1993) ITS primers with enhanced specificity for basidiomycetes - application to the identification of mycorrhizae and rusts. Mol Ecol 2:113-118

Gargas A, Taylor JW (1995) Phylogeny of Discomycetes and early radiations of the the apothecial Ascomycotina inferred from SSU rDNA sequence data. Exp Mycol 19:7-15

Gargas A, DePriest PT, Grube M, Tehler A (1995) Multiple origins of lichen symbioses in fungi suggested by SSU rDNA phylogeny. Science 268(5216): 1492-1495

Gaya E, Högnabba F, Holguin A, Molnar K, Fernández-Brime S, Stenroos S, Arup U, Søchting U, den Boom PV, Lücking R, Sipman HJM, Lutzoni F (2012) Implementing a cumulative supermatrix approach for a comprehensive phylogenetic study of the Teloschistales (Pezizomycotina, Ascomycota). Mol Phylogenet Evol 63:374-387

Gaya E, Fernández-Brime S, Vargas R, Lachlan RF, Gueidan C, RamírezMejía M, Lutzoni F (2015) The adaptive radiation of lichen-forming Teloschistaceae is associated with sunscreening pigments and a bark-to-rock substrate shift. PNAS 112:11600-11605
Graur D, Martin W (2004) Reading the entrails of chickens: molecular timescales of evolution and the illusion of precision. Trends Genet 20:80-86

Gueidan C, Ruibal C, De Hoog GS, Schneider H (2011) Rock-inhabiting fungi originated during periods of dry climate in the late Devonian and middle Triassic. Fungal Biol 115:987-996

Hasegawa M, Kishino H, Yano T (1985) Dating the human-ape splitting by a molecular clock of mitochondrial DNA. J Mol Evol 22:160 174

Hedges SB, Kumar S (2004) Precision of molecular time estimates. Trends Genet 20:242-247

Hennig W (1981) Insect phylogeny. John Wiley, New York

Hibbett DS, Binder M, Bischoff JF, Blackwell M, Cannon PF, Eriksson OE, Huhndorf S, James T, Kirk PM, Lücking R, Lumbsch HT, Lutzoni F, Matheny PB, McLaughlin DJ, Powell MJ, Redhead S, Schoch CL, Spatafora JW, Stalpers JA, Vilgalys R, Aime MC, Aptroot A, Bauer R, Bergerow D, Benny GL, Castlebury LA, Crous PW, Dai YC, Gams W, Geiser DM, Griffith GW, Gueidan C, Hawksworth DL, Hestmark G, Hosaka K, Humber RA, Hyde KD, Ironside JE, Kõljalg U, Kurtzman CP, Larsson KH, Lichtwardt R, Longcore J, Miądlikowska J, Miller A, Moncalvo JM, MozleyStandrige S, Oberwinkler F, Parmasto E, Reeb V, Rogers JD, Roux C, Ryvarden L, Sampaio JP, Schüßler A, Sugiyama J, Thorn RG, Tibell L, Untereiner WA, Walker C, Wang Z, Weir A, Weiß M, White MM, Winka K, Yao Y-J, Zhang N (2007) A higher level phylogenetic classification of the Fungi. Mycol Res 111:509-547

Huelsenbeck JP, Ronquist F (2001) MRBAYES: Bayesian inference of phylogenetic trees. Bioinformatics 17:754-755

Kaasalainen U, Heinrichs J, Krings M, Myllys L, Grabenhorst H, Rikkinen J, Schmidt AR (2015) Alectorioid morphologies in Paleogene lichens: new evidence and re-evaluation of the fossil Alectoria succini Mägdefrau. PLoS One 10(6):e0129526. doi:10.1371/journal.pone.0129526

Kirk PM, Cannon PF, Minter DW, Stalpers JA (2008) Ainsworth and Bisby's Dictionary of the Fungi, 10th edn. CABI, Wallingford, Oxon, UK

Lanfear R, Calcott B. Ho SYW, Guindon S (2012) PartitionFinder: combined selection of partitioning schemes and substitution models for phylogenetic analyses. Mol Biol Evol 29:1695-1701

Leslie AB, Beaulieu JM, Rai HS, Crane PR, Donoghue MJ, Mathews S (2012) Hemisphere-scale differences in conifer evolutionary dynamics. PNAS 109:16217-16221

Lumbsch HT, Huhndorf SM (2010) Myconet Volume 14. Part One. Outline of Ascomycota. Fieldiana Life Earth Sci 1:1-42

Lumbsch HT, Schmitt I, Palice Z, Wiklund E, Ekman S, Wedin M (2004) Supraordinal phylogenetic relationships of Lecanoromycetes based on a Bayesian analysis of combined nuclear and mitochondrial sequences. Mol Phylogenet Evol 31:822-832

Lumbsch HT, Lücking R, Tibell L (2009) Molecular data place Tylophoron as an additional calicioid genus in the Arthoniales (Ascomycota). Bibl Lichenol 99:285-296

Lutzoni F, Wagner P, Reeb V, Zoller S (2000) Integrating ambiguously aligned regions of DNA sequences in phylogenetic analyses without violating positional homology. Syst Biol 49:628-651

Maddison WP, Maddison DR (2001) MacClade: analysis of phylogeny and character evolution, version 4.01. Sinauer, Sunderland, Massachusetts

Magallón S, Gómez-Acevedo S, Sánchez-Reyes LL, HernándezHernández T (2015) A metacalibrated time-tree documents the early rise of flowering plant phylogenetic diversity. New Phytol 207:437453

McCune B, Rosentreter R (1992) Texosporium sancti-jacobi, a rare western North American lichen. Bryologist 95:329-333

Miadlikowska J, Kauff F, Hofstetter V, Fraker E, Grube M, Hafellner J, Reeb V, Hodkinson BP, Kukwa M, Lücking R, Hestmark G, Garcia Otalora M, Rauhut A, Büdel B, Scheidegger C, Timdal E, Stenroos 
S, Brodo I, Perlmutter G, Ertz D, Diederich P, Lendemer JC, May P, Schoch CL, Arnold AE, Gueidan C, Tripp E, Yahr R, Robertson C, Lutzoni F (2006) New insights into classification and evolution of the Lecanoromycetes (Pezizomycotina, Ascomycota) from phylogenetic analyses of three ribosomal RNA- and two protein-coding genes. Mycologia 98:1088-1103

Miadlikowska J, Kauff F, Högnabba F, Oliver JC, Molnár K, Fraker E, Gaya E, Hafellner J, Hofstetter V, Gueidan C, Otálora MAG, Hodkinson B, Kukwa M, Lücking R, Björk C, Sipman HJM, Burgaz AR, Thell A, Passo A, Myllys L, Goward T, FernándezBrime S, Hestmark G, Lendemer J, Lumbsch HT, Schmull M, Schoch CL, Sérusiaux E, Maddison DR, Arnold AE, Stenroos S, Lutzoni F (2014) Multigene phylogenetic synthesis for the class Lecanoromycetes (Ascomycota): 1307 fungi representing 1139 infrageneric taxa, 312 genera and 66 families. Mol Phylogenet Evol 79:132-168

Miller MA, Pfeiffer W, Schwartz T (2010) Creating the CIPRES Science Gateway for inference of large phylogenetic trees. In: Proceedings of the Gateway Computing Environments Workshop (GCE). New Orleans, LA, pp. 1-8

Myllys L, Lohtander K, Tehler A (2001) Beta-tubulin, ITS and group I intron sequences challenge the species pair concept in Physcia aipolia and P. caesia Mycologia 93:335-343

Nordin A (2004) New species in Tetramelas. Lichenologist 36:355-359

Nordin A, Tibell L (2005) Additional species in Tetramelas. Lichenologist 37:491-498

Nylander JAA, Wilgenbusch JC, Warren DL, Swofford DL (2008) AWTY (are we there yet?): a system for graphical exploration of MCMC convergence in Bayesian phylogenetics. Bioinformatics 24: $581-583$

Otálora MAG, Jørgensen PM, Wedin M (2014) A revised generic classification of the jelly lichens, Collemataceae. Fungal Divers 64:275293

Prieto M, Wedin M (2013) Dating the diversification of the major lineages of Ascomycota (Fungi). PLoS One 8(6):e65576. doi:10.1371 /journal.pone.0065576

Prieto M, Martínez M, Aragón G, Otálora MAG, Lutzoni F (2010) Phylogenetic study of Catapyrenium s. str. (Verrucariaceae, lichenforming Ascomycota) and related genus Placidiopsis. Mycologia 102:291-304

Prieto M, Baloch E, Tehler A, Wedin M (2013) Mazaedium evolution in the Ascomycota (Fungi) and the classification of mazaediate groups of formerly unclear relationship. Cladistics 29:296-308. doi: 10.1111/j.1096-0031.2012.00429.x

Rambaut A, Drummond AJ (2007) Tracer v1.4. http://beast.bio.ed.ac. $\mathrm{uk} /$ Tracer

Rambold G, Mayrhofer H, Matzer M (1994) On the ascus types in the Physciaceae (Lecanorales). Plant Syst Evol 192:31-40

Rehner S, Samuels GJ (1994) Taxonomy and phylogeny of Gliocladium analyzed from nuclear large subunits ribosomal DNA sequences. Mycol Res 98:625-634

Resl P, Schneider K, Westberg M, Printzen C, Zdeněk P, Thor G, Fryday A, Mayrhofer H, Spribille H (2015) Diagnostics for a troubled backbone: testing topological hypotheses of trapelioid lichenized fungi in a large-scale phylogeny of Ostropomycetidae (Lecanoromycetes). Fungal Divers 73:239-258

Rikkinen J (2003) Calicioid lichens from European Tertiary amber. Mycologia 95:1032-1036

Rodríguez F, Oliver JF, Marin A, Medina JR (1990) The general stochastic model of nucleotide substitution. J Theor Biol 142:485-501

Röhl U, Bralower TJ, Norris RD, Wefer G (2000) New chronology for the late Paleocene thermal maximum and its environmental implications. Geology 28:927-930

Ronquist F, Teslenko M, Mark P van der, Ayres D, Darling A, Höhna S, Larget B, Liu L, Suchard MA, Huelsenbeck J P (2011) MrBayes
3.2: Efficient Bayesian phylogenetic inference and model choice across a large model space. Syst Biol 61:539-542

Rutschmann F, Eriksson T, Salim KA, Conti E (2007) Assessing calibration uncertainty in molecular dating: the assignment of fossils to alternative calibration points. Syst Biol 56:591-608

Sauquet H, Ho SYW, Gandolfo MA, Jordan GJ, Wilf P, Cantrill DJ, Bayly MJ, Bromham L, Brown GK, Carpenter RJ, Lee DM, Murphy DJ, Sniderman JMK, Udovicic F (2012) Testing the impact of calibration on molecular divergence times using a fossil-rich group: the case of Nothofagus (Fagales). Syst Biol 61:289-313

Schmitt I, Crespo A, Divakar PK, Fankhauser JD, Herman-Sackett E, Kalb K, Nelsen MP, Nelson NA, Rivas-Plata E, Shimp AD, Widhelm T, Lumbsch HT (2009) New primers for promising single-copy genes in fungal phylogenetics and systematics. Persoonia 23:35-40

Silvestro D, Cascales-Miñana B, Bacon CD, Antonelli A (2015) Revisiting the origin and diversification of vascular plants through a comprehensive Bayesian analysis of the fossil record. New Phytol 207:425-436

Singh G, Divakar PK, Dal Grande F, Otte J, Parnmen S, Wedin M, Crespo A, Lumbsch HT, Schmitt I (2013) The sister group relationships of the largest family of lichenized fungi, Parmeliaceae (Lecanorales, Ascomycota). Fungal Biol 117:715-721

Stamatakis A (2014) RAxML Version 8: A tool for phylogenetic analysis and post-analysis of large phylogenies. Bioinformatics 30:13121131

Tehler A, Baloch E, Tibell L, Wedin M (2009) The systematic position of Schistophoron. Bibl Lichenol 99:383-392

Tibell L (1969) The genus Cyphelium in northern Europe. Sven Bot Tidskr 63:465-485

Tibell L (1971) The genus Cyphelium in Europe. Sven Bot Tidskr 65: 138-164

Tibell L (1975) The Caliciales of boreal North America. Taxonomy, ecological and distributional comparisons with Europe, and ultrastructural investigations in some species. Symbolae Bot Upsaliensis 21:1-128

Tibell L (1976) The genus Thelomma. Bot Notiser 129:221-249

Tibell L (1984) A reappraisal of the taxonomy of Caliciales. Beih Nova Hedwigia 79:597-713

Tibell L (2003) Tholurna dissimilis and generic delimitations in Caliciaceae inferred from nuclear ITS and LSU rDNA phylogenies (Lecanorales, lichenized ascomycetes). Mycol Res 107:1403-1418

Tibell L (2006) Calicium in the Indian Himalayas. J Hattori Bot Lab 100: 809-851

Tibell L, Ryan BD (2004) Cyphelium. - In: Nash III TH, Ryan BD, Diederich P, Gries C, Bungartz F (eds.) Lichen Flora of the Greater Sonoran Desert Region, Vol. 2. Lichens Unlimited, Arizona State University, Tempe, Arizona, pp 82-88

Tibell L, von Hofsten AV (1968) Spore evolution of the lichen Texosporium sancti-jacobi (=Cyphelium sancti-jacobi). Mycologia 60:553-558

Vilgalys R, Hester M (1990) Rapid genetic identification and mapping of enzymatically amplified ribosomal DNA from several Cryptococcus species. J Bacteriol 172:4238-4246

Wedin M, Grube M (2002) Proposal to conserve Physciaceae nom. cons. against an additional name Caliciaceae (Lecanorales, Ascomycota). Taxon 51:802

Wedin M, Tibell L (1997) Phylogeny and evolution of Caliciaceae, Mycocaliciaceae and Sphinctrinaceae (Ascomycota), with notes on the evolution of the prototunicate ascus. Can J Bot 75:1236-1242

Wedin M, Döring H, Nordin A, Tibell L (2000) Small subunit rDNA phylogeny shows the lichen families Caliciaceae and Physciaceae (Lecanorales, Ascomycotina) to form a monophyletic group. Can J Bot 78:246-254

Wedin M, Baloch E, Grube M (2002) Parsimony analyses of mtSSU and nITS rDNA sequences reveal the natural relationships of the lichen families Physciaceae and Caliciaceae. Taxon 51:655-660 
Wedin M, Wiklund E, Crewe A, Döring H, Ekman S, Nyberg Å, Schmitt I, Lumbsch HT (2005) Phylogenetic relationships of Lecanoromycetes (Ascomycota) as revealed by analyses of mtSSU and nLSU rDNA sequence data. Mycol Res 109:159-172

Westberg M, Millanes A, Knudsen K, Wedin M (2015) Phylogeny of Acarosporaceae (Lecanoromycetes, Ascomycota, Fungi) and the evolution of carbonized ascomata. Fungal Divers 73:145-158

White TJ, Bruns T, Lee S, Taylor JW (1990) Amplification and direct sequencing of fungal ribosomal RNA genes for phylogenetics. In: Innis MA, Gelfand DH, Sninsky JJ, White TJ (eds) PCR Protocols: A Guide to Methods and Applications. Academic Press, Inc., New York, pp. 315-322

Wilgenbusch J C, Warren DL, Swofford DL (2004) AWTY: A system for graphical exploration of MCMC convergence in Bayesian phylogenetic inference http://ceb.csit.fsu.edu/awty.

Zharkikh A (1994) Estimation of evolutionary distances between nucleotide sequences. J Mol Evol 39:315-329

Zoller S, Scheidegger C, Sperisen C (1999) PCR primers for the amplification of mitochondrial small subunit ribosomal DNA of lichenforming ascomycetes. Lichenologist 31:511-516 